\title{
Effects of Storage on Some Physico-Chemical Characteristics of UHT Milk Stored at Different Temperature
}

\author{
Aldubhany, T.A. W.; Gouda, Effat; Khattab, A; Dabour, Nasra. ${ }^{1}$
}

\begin{abstract}
Raw milk for UHT processing at commercial dairy plant was collected from well managed dairy farms. The milk was processed by direct system and heated at 143$145^{\circ} \mathrm{C}$ for $3-5_{\mathrm{S}}$, then aseptically packed. Three different batches of UHT milk were used in this study. Samples of UHT milk were analysed after processing and during storage at 4,22 and $37^{\circ} \mathrm{C} \pm 2^{\circ} \mathrm{C}$ for 6 months. The changes in $\mathbf{p H}$, acidity as lactic acid, total solids, viscosity, fat content, electrical conductivity, specific gravity nonprotein nitrogen, non-casein nitrogen total and soluble calcium, magnesium, citrate, and phosphorus during storage were studed. The samples were analysed at $0,30,60,90,120,150$ and 180 days for the physico-chemical proportes of milk. Values indicate an increase in acidity,viscocity,NCN,NPN, soluble calcium magnesium citrate and phosphate.The results showed after statistically analysis that there is a significant affect of storage period and storage temperature on $\mathrm{pH}$, titratable acidity, non protein- nitrogen, non-casein nitrogen, viscosity, soluble and colloidal calcium and phosphate, soluble magnesium and citrate. There are a significant decrease in $\mathrm{pH}$, electrical conductivity, by increasing storage period, with increasing in acidity ratio, non- protein- non-casein nitrogen and viscosity.
\end{abstract}

\section{INTRODUCTION}

Consumers demand foods that are as fresh as possible with good sensory properties, additionally being safe and having a substantial shelf life, yet without application of additives. Because of its high nutritional value, milk is an excellent medium for microbiological growth. Consequently, fresh milk necessitates a heat treatment in order to guarantee a safe and shelf stable product. The most commonly applied technique to achieve this is heat treatment (Chavan, et al 2011).

Ultra-high temperature (UHT) treatment of milk is a heating process at very high temperatures for short holding times, which renders the milk commercially sterile and gives a product with a long shelf life at ambient temperatures. UHT treatments are usually carried out at temperatures of $140{ }^{\circ} \mathrm{C}$ for $4-6$ s. (Gaucher, et al 2008) During heat treatment, chemical, physical and biochemical reactions take place. These changes are significant because they influence nutritional, sensorial and microbiological aspects of milk. Most bacteria are inactivated but heat-stable enzymes of native or bacterial origin can survive and give rise, during storage, to both gelation and offflavours (bitter, stale and oxidised) (Burton, 1988).

Gelation is the major physical state change which usually related to protein breakdown (Harwalkar, 1982). It is manifested by a rise in viscosity before formation of a gel and loss of fluidity. This phenomenon, which is irreversible, is known as 'age gelation'. Different causes and mechanisms have been proposed to explain this defect, and proteolysis has often been suspected (Datta and Deeth 2001; McMahon 1996). Proteolysis of UHT milk during storage at room temperature is a major factor limiting the shelf life through changes in its flavour and texture (Datta et al., 2002).

A certain level of proteolysis is required to induce age gelation, the relation between gelation time and extent of proteolysis is controversial (Manji and Kakuda, 1988; Newstead et al., 2006).

The aim of the current study was to investigate susceptibility of UHT milk during storage at different temperature up to 180 days to proteolysis and studying the global changes of physico-chemical composition during storage.

\section{MATERIALS AND METHODS}

\section{Materials}

\section{Raw milk samples}

Three different batches of raw milk (A, B and C) were collected from several well managed dairy farms were heat treated to produce UHT milk.

\section{Manufactured of UHT milk}

The UHT milk batches were processed on famous milk factory using direct (Infusion) heating at 143$145^{\circ} \mathrm{C}$ for 3-5 s, homogenized downstream using a 2stage aseptic homogenizer operating at 150 and 50 bar in the first and second stages, respectively. The UHT processed milks were filled aseptically in1 liter Tetra Pak.

\section{UHT milk samples}

UHT samples of three batches (A. B, C) were obtained immediately after processing. Each batches was divided to three group the first was stored at refrigerator temperature $\left(4 \pm 2{ }^{\circ} \mathrm{C}\right)$ the second at room

\footnotetext{
${ }^{1}$ Alexandria University, Faculty of Agriculture, Department of Dairy Science and Technology

Received May 5, 2014, Accepted June17, 2014
} 
temperature $\left(22 \pm 2{ }^{\circ} \mathrm{C}\right)$ and the third at incubator temperature $\left(37 \pm 2{ }^{\circ} \mathrm{C}\right)$.

The stored samples were examined, fresh (just after processing) and every 30 days up to 180 days.

\section{Analytical methods}

The $\mathrm{pH}$ values were determined either in raw milk or UHT milk by using Philips pH meter type 9418/30 with combined electrode at $20 \pm 2{ }^{\circ} \mathrm{C}$.

The total acidity (as lactic acid) and specific gravity of milk were determined according to AOAC (2005).

The fat content was determined according to the AOAC (2005) by Rose-Gottlieb process extraction method using diethyl ether, petroleum ether and ethanol.

The electrical conductivity was measured by using a Radiometer conductivity type CDM2C.

The viscosity was measured at $20^{\circ} \mathrm{C}$ under constant conditions using a Hoppler viscometer type $\mathrm{BH}$. The viscosity expressed in centipoises (cp) and calculated by using special formula and table supplied with the viscometer.

Nitrogen fractions (total nitrogen, non-casein nitrogen and non-protein nitrogen) of milk, total calcium, magnesium, citrates and phosphates content were determined according to the method described in AOAC (2005).

The resulting filtrate of non-protein nitrogen was used to determine the soluble calcium magnesium, citrates and phosphates content following the method described by A.O.A.C. (2005).

\section{Statistical Analysis}

The data were analyzed according to statistical procedure of analysis of variance (ANOVA), and in case of significant differences, the mean were further computed using least significant difference (LSD) at 0.05 level of probability through computerized statistical package i.e, Student Edition of Statistics (MSTAT-C), version 8.1 (Copyright 1996, Analytical software, USA).

\section{RESULTS AND DISCUSSION}

\section{The chemical analysis of UHT milk during storage}

The gross chemical composition of UHT milk samples in this study presented in table 1 . The changes that have taken place during storage dependent on temperature of storage. The $\mathrm{pH}$ values were decreased gradually during storage from 6.73 to $6.53,6.71$ to 6.50 and 6.70 to 6.36 at $4 \pm 2,22 \pm 2$ and $37 \pm 2{ }^{\circ} \mathrm{C}$ respectively after 6 month of storage (table 1). This data indicated that the highest $\mathrm{pH}$ decrease was reported at $37{ }^{\circ} \mathrm{C}$. Correspondingly, the decrease in $\mathrm{pH}$ values of UHT milk from powder milk was reported by Ernani et al., (1997), the authors showed that the rate of decrease was greater at $25 \pm 1{ }^{\circ} \mathrm{C}$ than at $3 \pm 1{ }^{\circ} \mathrm{C}$ and after 6 months of storage. Gaucher et al., 2008, Venkatachalam et al., 1993, Celestino et al., 1997 and Telles et al., 2007 found that decrease in $\mathrm{pH}$ during 6 months of storage at 4, 20 and $40{ }^{\circ} \mathrm{C}$ and the highest changes was at $40{ }^{\circ} \mathrm{C}$. The changes in $\mathrm{pH}$ values started after 30,60 and 90 days of storage at 4,22 and $37 \pm 2^{\circ} \mathrm{C}$, respectively and the massive $\mathrm{pH}$ decrease was observed after 180 days of storage at 22 and $37 \pm 2{ }^{\circ} \mathrm{C}$. Similar results were reported by El-Dakhakhny (1990), who found that the $\mathrm{pH}$ decreased with increasing the storage heat temperature and the highest decrease was after 180 days after incubation at room temperature. While Kawady (2004) concluded that the milk type and storage temperature had no significant effect on $\mathrm{pH}$ value, while storage period had significant effect on $\mathrm{pH}$. Putative solution for $\mathrm{pH}$ decrease illustrated by Vujicic et al., (1991) who mentioned that adjusting $\mathrm{pH}$ from 6.4 to 6.6 with $\mathrm{NaOH}$ improved the UHT-sterilized recombined concentrate stability during the first 30 days of storage. Highly significantly changes in $\mathrm{pH}$, acidity non protein nitrogen $(\mathrm{NPN})$ and non casein nitrogen $(\mathrm{NCN})(p \leq$ $0.05)$ were observed during storage at $37 \pm 2{ }^{\circ} \mathrm{C}$. Meanwhile, no significant changes were recorded for fat and total solids determination for all tested samples at temperature/times of storage (table 1).

Consequently, the titratable acidity was increased gradually during storage from 0.142 to $0.154,0.143$ to 0.160 and 0.146 to 0.164 at $4 \pm 2,22 \pm 2$, and $37 \pm 2{ }^{\circ} \mathrm{C}$ respectively after 6 month of storage (table 1). Moreover, the statistical analysis indicated that the storage period had a significant effect on titratable acidity in all batches these results were in agreement with Fink and Kessler, (1986), Mehanna Gone (1988) they found that there was a progress relation between the acidity of UHT milk samples and storage time. Rerkrai et al., (1997) reported that the increase in acidity were slightly greater in UHT samples stored at room temperature than that stored under refrigeration. While Kawady (2004) concluded that the milk type and storage temperature had no significant effect on acidity, while storage period had significant effect on acidity.

Also table 1 showed that total solids (TS) content were ranged between 11.69 to $12.47 \%$ among the samples. Present results showed no significant differences in the total solids values of UHT milk samples during storage at different temperatures. The statistical analysis showed that the storage period had no significant effect on total solids in all batches. These results were agreed with Barbano et al., (2006). (1987). While Telles et.al., (2007) performed a trial to characterize 30 samples of raw milk and 
Table 1. Chemical analysis of UHT milk stored at different temperatures

\begin{tabular}{|c|c|c|c|c|c|}
\hline $\begin{array}{c}\text { Storage } \\
\text { temp. }\left({ }^{\circ} \mathrm{C}\right)\end{array}$ & $\begin{array}{c}\text { Storage } \\
\text { time(days) }\end{array}$ & pH & Acidity\% & Fat\% & Total Solids (TS \%) \\
\hline \multirow{7}{*}{$4 \pm 2{ }^{\circ} \mathrm{C}$} & 0 & 6.73 & 0.1417 & 3.263 & 11.697 \\
\hline & 30 & 6.72 & 0.1417 & 3.263 & 11.697 \\
\hline & 60 & 6.70 & 0.1427 & 3.263 & 11.727 \\
\hline & 90 & 6.63 & 0.1463 & 3.223 & 11.800 \\
\hline & 120 & 6.58 & 0.1487 & 3.237 & 11.877 \\
\hline & 150 & 6.55 & 0.1507 & 3.187 & 12.060 \\
\hline & 180 & 6.53 & 0.1537 & 3.167 & 12.240 \\
\hline \multirow{7}{*}{$22 \pm 2{ }^{\circ} \mathrm{C}$} & 0 & 6.71 & 0.1430 & 3.263 & 11.697 \\
\hline & 30 & 6.67 & 0.1450 & 3.253 & 11.698 \\
\hline & 60 & 6.63 & 0.1478 & 3.233 & 11.757 \\
\hline & 90 & 6.59 & 0.1500 & 3.22 & 11.850 \\
\hline & 120 & 6.55 & 0.1533 & 3.203 & 11.920 \\
\hline & 150 & 6.52 & 0.1570 & 3.187 & 12.130 \\
\hline & 180 & 6.48 & 0.1603 & 3.156 & 12.470 \\
\hline \multirow{7}{*}{$37 \pm 2{ }^{\circ} \mathrm{C}$} & 0 & 6.70 & 0.1463 & 3.263 & 11.680 \\
\hline & 30 & 6.54 & 0.1527 & 3.263 & 11.698 \\
\hline & 60 & 6.51 & 0.1540 & 3.233 & 11.777 \\
\hline & 90 & 6.49 & 0.1563 & 3.233 & 11.850 \\
\hline & 120 & 6.45 & 0.1590 & 3.207 & 12.037 \\
\hline & 150 & 6.41 & 0.1613 & 3.197 & 12.193 \\
\hline & 180 & 6.36 & 0.1638 & 3.154 & 12.244 \\
\hline L.S.D. ${ }_{0.05}$ & & 0.0784 & 0.0034 & $\mathrm{~ns}$ & ns \\
\hline
\end{tabular}

LSD: Least significant difference. TS: Total solids, ns: not significant.

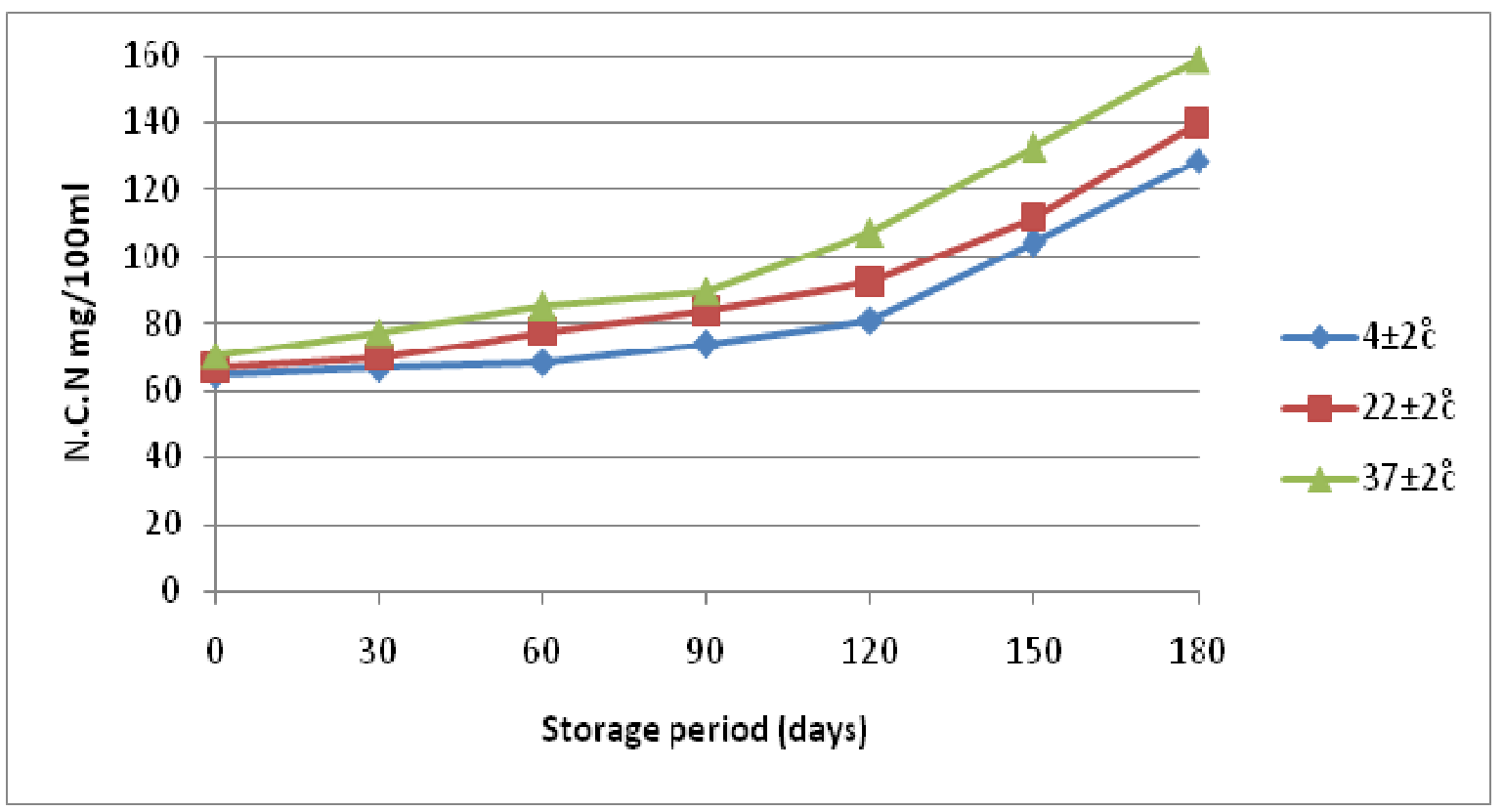

Fig.1. Effect of different storage periods and different storage temperature on $\mathrm{NCN}$ *content of different UHT milk samples

$\mathrm{NCN}^{*}$ : non casein nitrogen. 
the corresponding UHT whole milk obtained by direct heating in Sea Paulo, the authors found significant decrease in measured total solids during storage.

NCN average in freshly processed UHT milk was ranged between 64.66 to $70.39 \mathrm{mg} / 100 \mathrm{ml}$ (Fig. 1), After 180 days of storage, NCN content increased gradually to $128.91,139.96$ and $159.61 \mathrm{mg} / 100 \mathrm{ml}$ for milk samples stored at 4,22 and $37 \pm 2{ }^{\circ} \mathrm{C}$, respectively (Fig. 1). These increases in $\mathrm{NCN}$ content were significant for all tested storage temperatures. The higher storage temperature $\left(37 \pm 2{ }^{\circ} \mathrm{C}\right)$ had the higher NCN content generally.

The initial value for the NPN content was ranged between 37.65 to $40.52 \mathrm{mg} / 100 \mathrm{ml}$, and gradually increased to $55.25,58.71$ and $63.84 \mathrm{mg} / 100 \mathrm{ml}$ after storage for 180 days at 4,22 and $37 \pm 2{ }^{\circ} \mathrm{C}$ respectively (Fig. 2). The significant changes of NPN were observed after 30 and 90 days of storage at $4{ }^{\circ} \mathrm{C}, 22$ and $37 \pm 2{ }^{\circ} \mathrm{C}$ respectively. These increases, suggest proteolysis during storage, which also reported by Gaucher et al., 2008 whereas, El-Din et.al., 1991 found that both NCN and NPN where increased during 150 days of storage, and the increments were larger at 30 than $5^{\circ} \mathrm{C}$. In the other side, Kawady (2004), concluded that the milk type and storage period had significant effect on total nitrogen, non-protein nitrogen, non-casein nitrogen, casein nitrogen, while storage temperature had no significant effect on total nitrogen, non-protein nitrogen casein nitrogen and non -casein nitrogen.

The determination of minerals (calcium, phosphate, magnesium and citrate) contents and stability for tested UHT milk samples during storage at various temperatures is presented in table 2. The minerals values for freshly processed UHT milk were $40.44 \pm$ $0.27,36.43 \pm 0.04,7.25 \pm 0.07$ and $126.37 \pm 0.05 \mathrm{mg} /$ $100 \mathrm{~mL}$ of soluble calcium, phosphate, magnesium and citrate respectively and $82.58 \pm 0.02,55.48 \pm 0.01,2.11$ \pm 0.04 and $10.9 \pm 0.0$ for the colloidal form of the same minerals. The equilibrium of calcium between soluble and colloidal phase is very important phenomenon for milk stability and bioavailability (Singh 2007). Therefore, the partitioning of calcium between the dissolved and colloidal phases was studied during storage of the UHT milk samples at different temperatures. Normally the distribution of original calcium of milk is about one-third of the natural calcium presents in the dissolved state in cow milk. The results in table 2 revealed that calcium content in fresh UHT milk samples was $40.44 \pm 0.27 \mathrm{mg} / 100 \mathrm{~mL}$ and the colloidal contents was $82.58 \pm 0.02 \mathrm{mg} / 100 \mathrm{~mL}$ these results are agree with the corresponding results obtained by Singh (2007) and El-Dakhakhny (1990). This ratio was changed during the storage as the soluble calcium was increased gradually during storage from 40.20 to $50.87,40.38$ to 53.88 and 40.74 to $54.88 \mathrm{mg} / 100 \mathrm{ml}$ at $4 \pm 2,22 \pm 2$ and $37 \pm 2{ }^{\circ} \mathrm{C}$ respectively after 6 month of storage (table 2).

The determination of soluble and colloidal phosphate presented in table (2) revealed an increasing in soluble phosphate during storage from 36.40 to $36.90,36.41$ to 37.15 and 36.47 to $37.33 \mathrm{mg} / 100 \mathrm{ml}$ at $4 \pm 2,22 \pm 2$ and $37 \pm 2{ }^{\circ} \mathrm{C}$ respectively after 6 month of storage. While the colloidal phosphate recorded a slight decline almost does not mention gradually during the 180 days of storage (table 2) and did not affect by the storage temperatures. The changes in soluble calcium and phosphate contents may attributed to the high heat treatment of $140{ }^{\circ} \mathrm{C}$, used in this study and the decreased of the $\mathrm{pH}$ values during storage especially at the elevated temperature of $37^{\circ} \mathrm{C}$. pouliot et al., (1989), found that increasing the temperature used in the preparation of UHT milk results in the transfer of the soluble calcium and phosphate to the colloidal phosphate, with a concomitant decrease in milk $\mathrm{pH}$. Also, El-Dakhakhny (1990) showed that no alteration in total calcium and total phosphorus contents by heat treatment while a clear changes are observed in soluble calcium and phosphore during storage. The author proved a progressive decrease in soluble calcium and phosphorus contents with increasing time and temperature of storage.

\section{The physical analysis of UHT milk}

Table (3) presents the physical changes of UHT milk samples during storage under different temperatures. The statistical analysis showed that there are no significant differences in viscosity between batches (data not shown), while the viscosity were increased gradually during storage from 1.337 to1.877, 1.382 to 2.07 and 1.393 to $2.237 \mathrm{cp}$ after 6 month of storage at $4 \pm 2,22 \pm 2$ and $37 \pm 2{ }^{\circ} \mathrm{C}$ respectively. The significant increase in viscosity started after 30 days of storage at all storage temperatures while the highest changes were reported after 120 and 90 days of storage at 22 and $37{ }^{\circ} \mathrm{C}$ respectively (table 3 ). These results concluded that the storage period had a great significant effect $(p \leq 0.05)$ on the viscosity of stored UHT milk samples even at refrigerated temperature. These results are agree with the corresponding results determined by Ernani et al., (1997). Also, Kawady (2004) concluded that the milk type and storage period had significant effect on viscosity, while the storage temperature had no significant effect on viscosity. El-Dakhakhny (1990), found that the different storage temperatures and storage periods had clear effect on viscosity. 


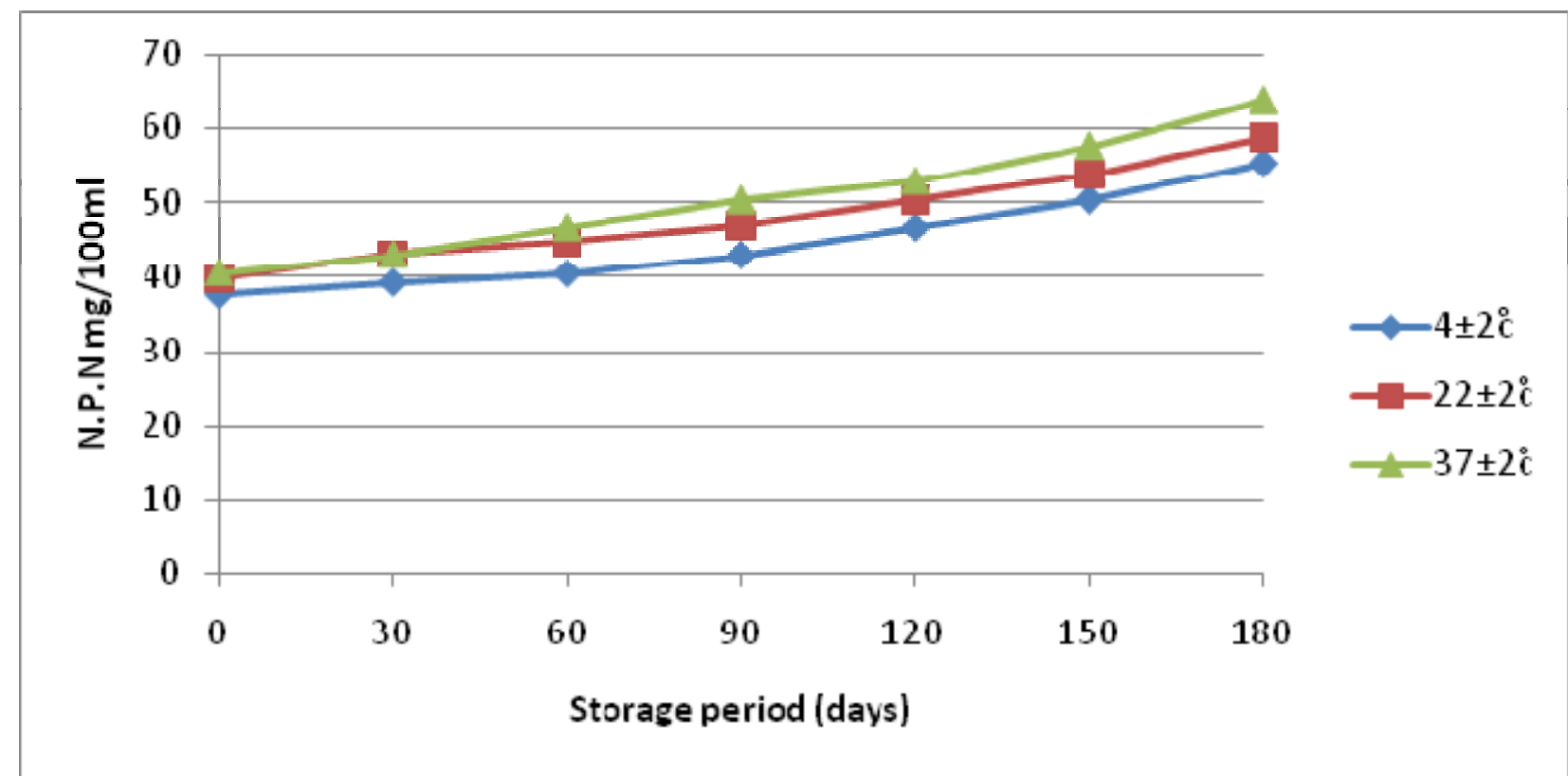

Fig.2. Effect of different storage periods and different storage temperature on NPN* content of different UHT milk samples

NPN*: non protein nitrogen.

Table 3. Physical analysis of UHT milk storage at different temperature

\begin{tabular}{|c|c|c|c|c|}
\hline \multirow[t]{2}{*}{ Storage temp. $\left({ }^{\circ} \mathrm{C}\right)$} & \multirow{2}{*}{$\begin{array}{c}\text { Storage } \\
\text { time(days) }\end{array}$} & \multicolumn{3}{|c|}{ Physical characters } \\
\hline & & Viscosity (cp) & $\begin{array}{l}\text { Electrical conductivity } \\
(\mathrm{EC})(\mathrm{Umhos} / \mathrm{cm})\end{array}$ & Specific gravity \\
\hline \multirow[t]{7}{*}{$4 \pm 2{ }^{\circ} \mathrm{C}$} & 0 & 1.337 & 6.800 & 1.032 \\
\hline & 30 & 1.475 & 6.733 & 1.032 \\
\hline & 60 & 1.587 & 6.433 & 1.033 \\
\hline & 90 & 1.760 & 5.867 & 1.033 \\
\hline & 120 & 1.673 & 5.800 & 1.034 \\
\hline & 150 & 1.803 & 5.267 & 1.035 \\
\hline & 180 & 1.877 & 4.600 & 1.036 \\
\hline \multirow[t]{7}{*}{$22 \pm 2{ }^{\circ} \mathrm{C}$} & 0 & 1.382 & 6.600 & 1.032 \\
\hline & 30 & 1.677 & 6.670 & 1.033 \\
\hline & 60 & 1.793 & 5.367 & 1.033 \\
\hline & 90 & 1.807 & 5.267 & 1.034 \\
\hline & 120 & 1.880 & 4.800 & 1.034 \\
\hline & 150 & 2.030 & 4.267 & 1.035 \\
\hline & 180 & 2.070 & 4.030 & 1.036 \\
\hline \multirow[t]{7}{*}{$37 \pm 2^{\circ} \mathrm{C}$} & 0 & 1.393 & 6.570 & 1.032 \\
\hline & 30 & 1.810 & 5.567 & 1.033 \\
\hline & 60 & 1.823 & 6.500 & 1.033 \\
\hline & 90 & 1.900 & 5.333 & 1.034 \\
\hline & 120 & 2.017 & 5.000 & 1.034 \\
\hline & 150 & 2.127 & 4.470 & 1.035 \\
\hline & 180 & 2.237 & 4.220 & 1.039 \\
\hline L.S.D. ${ }_{0.05}$ & & 0.134 & 0.317 & 0.00162 \\
\hline
\end{tabular}

LSD: Least significant difference. cp: centipoises. Umhos/cm: Micromhos /cm 
Electrical conductivity determination showed no significant differences in electrical conductivity between batches of fresh UHT milk then decreased gradually from 6.80 to $4.60,6.60$ to 4.03 and 6.57 to 4.22 after 6 month of storage at $4 \pm 2,22 \pm 2$ and $37 \pm 2{ }^{\circ} \mathrm{C}$, respectively (table 3 ). The statistical analysis indicated that the storage period had significant effect on conductivity in all batches. The specific gravity were increased gradually during storage from 1.032 to 1.035 , 1.032 to 1.036 and 1.032 to 1.039 after 6 month of storage at $4 \pm 2{ }^{\circ} \mathrm{C}, 22 \pm 2{ }^{\circ} \mathrm{C}$ and $37 \pm 2{ }^{\circ} \mathrm{C}$, respectively.

A cording to the physico-chemical characteristics of UHT milk, it can be notices that storage period effect is more than the effect of storage temperature. The appearance of undesirable changes were started in UHT milk stored at $37 \pm 2{ }^{\circ} \mathrm{C}, 22 \pm 2{ }^{\circ} \mathrm{C}$ and $4 \pm 2{ }^{\circ} \mathrm{C}$ after 90,120 and 180 days of storage, respectively.

\section{REFERENCES}

A.O.A.C Official Method 942.05 (2005). Official Methods of Analysis AOAC International. 18th edition. Gaithersburg, MD, USA: AOAC International.

Barbano, D.M, Ma Y, and Santos, M.V. (2006). Influence of raw milk quality on fluid milk shelf life. J Dairy Sci 89(Suppl E):E15-9.

Bastian, E. D. and Brown, R. J. (1996). Plasmin in milk and dairy products: An update, Int Dairy J, 6(5): 435-457.

Burton, H. (1988). Ultra-High-Temperature processing of milk and milk products. Elsevier Applied Science, London. $354 \mathrm{p}$.

Celestino, E. L. Iyer, M. and Roginski, H. (1997). Reconstituted UHTtreated milk: Effects of raw milk, powder quality and storage conditions of UHT milk on its physico-chemical attributes and flavour. International Dairy Journal, 7, 129-140.

Chavan,R.S.; Chavan,S.R.; Chandrashekar, D. Khedkar and Atanu, H. Jana. (2011). UHT Milk Processing and Effect of Plasmin Activity on Shelf Life. A reviews in Food Science and Food Safety 10: 251-268.

Datta, N., Elliot, A.J., Perkin, M.L. and Deeth, H.C. (2002). UHT treatment of milk: comparison of direct and indirect methods of heating. Australian Dairy Technolo. 57: 211257.

Datta, N.and Deeth, H.C. (2001). Age gelation of UHT milk-a review. Trans IChemE 79:197-210.

El-dakhakhny,E.A.(1990).Chemical and Technological Studies on milk: Physico-Chemical-Microbiological studies on UHT milk., Ph.D. Thesis (University of Alexandaria).

El-din, M.Z.; Aoki, T. and Kako, Y. (1991). Polymerization and degradation of casein in UHT milk during storage, Milchwissenschaft. 46:284-287.
Ernani, L., M. Lyer, Celestino and H. Roginski (1997).Reconstituted UHT treated milk, effects of raw milk, powder quality and storage condition of UHT milk on its physio-chemical attributes and flavor.Intl. Dairy J., 7:129-140.

Fink, R. and Kessler, H.G. (1986). Changes in heated and stored milk with an interpretation by reaction kinetics. Journal of Food Science V51 (5):1105-1111

Fox, P.F. and Kelly, A.L.(2006). Indigenous enzymes in milk: Overview and historical aspects-Part 1. International Dairy Journal, 16: 500-516.

Fox, P.F. and P.L.H. McSweeney (eds) (2003). Advanced Dairy Chemistry-I. Proteins, 3rd. Edition, Kluwer Academic/Plenum Publishers, New York 1346 pp.

Gaucher, I., Mollé, D., Gagnaire, V. and Gaucheron, F. (2008). Effects of storage temperature on physicochemical characteristics of semi-skimmed UHT milk. Food Hydrocoll 22:130-143.

Harwalkar, V. R. (1982). Age gelation of sterilized milks, Development in Dairy Chemistry, Volume 1: Proteins, Fox, P. F. (ed.) (Elsevier Science Publishers Ltd., London), pp. 229-269.

Kawady,E.A.(2004). Chemical and bacteriological studies on UHT milk. Animal production Research Institute (APRI).

Manji, B. and Kakuda, Y. (1988). The role of protein denaturation, extent of proteolysis, and storage temperature on the mechanism of age gelation in a model system. Journal of Dairy Science, 71, 1455e1463.

Mehanna,N.M. and Gone,S. (1988). The changes in composition and properties of directly and properties of directly and indirectly processed UHT milk during storage. Pakistan J. Sci. and industrial res. (1998) 31527531.

McMahon, DJ. (1996). Age-gelation of UHT milk: changes that occur during storage, their effect on shelf life and the mechanism by which age-gelation occurs. In: IDF special issue, heat treatments and alternative methods. I D F, Brussels, pp 315-326.

MSTAT-C. (1996). Russel, D.Freed, MSTAT Director, crop and soil sciences Department, Michigan state University, USA.

Newstead, D. F., Paterson, G., Anema, S. G., Coker, C. J., and Wewala, A. R. (2006). Plasmin activity in direct-steaminjection UHT-processed reconstituted milk: effects of preheat treatment. International Dairy J.16: 573-579.

Pereda, J., Ferragut, V., Quevedo, J.M., Guamis, B. and Trujillo, A.J. (2008). Effects of ultra-high pressure homogenization on microbial and physicochemical shelf life of milk. J Dairy Sci 90:1081-1093.

Pouliot, Y., Boulet, M. and Paquin, P. (1989). 'Observations on the Heat Induced Salt Balance Changes in Milk. I Effect of Heating time between 4 and $90^{\circ} \mathrm{C}$. J. Dairy Res. 56: 185-192. 
Rerkrai, S.I, Jeon.IT., and Bassette,R.(1997). Effect of various direct ultra-high -temperature heat treatments on flavor of commercially prepared milk. J. Dairy Sci. 70:2046-2054.

Singh, R.K. (2007). Advances in thermal and non-thermal food preservation. Ames, Iowa: Blackwell Publishing. P 43-61.

Sørhaug, T., Stepaniak, L. (1997). Psychrotrophs and their enzymes in milk and dairy products: quality aspects. Trends Food Sci Technol 8:35-41.
Telles,Simone Balion, Carlos fernandes, L. P, Antonio, F. T. and Paule Silva, J. P.(2007). UHT whole milk: Evaluation of some quality parameters in raw and processed milk. Vet.Ezootec, 14: 282-290.

Venkatachalam, N., McMahon, D. J. and Savello, P. A. (1993). Role of protein and lactose interactions in the age gelation of ultra-high temperature processed concentrated skim milk. J. Dairy Sci. 76: 1882-1894.

Vujicic, I.F., Vulic, M., Neketic, G., Holsinger. V.H.(1991).Sediment formation in UHT recombined concentrates during storage. I D F. (1990) 544 ISBN 09694713-4-3.

\section{الملذص العري}

\section{تأثير درجة حرارة النخزن عل بهض الخواص الفيزوكيماوبة للبن المعالل بالنسخين الفاكق (UHT) والمخزن عل درجل حرارةمختالة}

وهيب علي ثابت الذبحاني، كغت جوة،علي خطلب، نصرة دبور

الذائب والماغنسيوم والفوسفلت وللسترات الذائب وأن

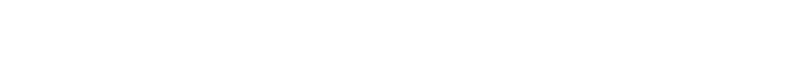
من الحموضة واللزوجة والـ - pH والنيتروجين الغير بروتيف والغيركازيي والتوصيل الكهربه والوزن النوعى والكللسيوم الذائب والغروى والفوسفات وللسترات الذائب

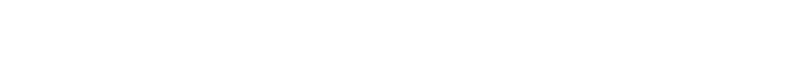
الكلية والفوسفات وللسترات الغروى.

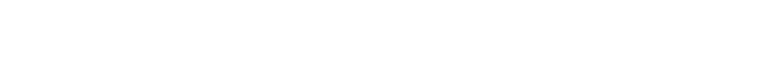
مدة التخزين ودرجة حرارة التخزين على كلاً من الحموضة التهمائل واللزوجة وال _pH والنيتروجين ال لـا بروتيني والنيتروجين اللا كازيفي والتوصيل الكهرب والوزن النوعى والكللسيوم الذائب والغروى والفوسفات وللسترات الذائب.
لدرلسة العوالمل الطبيعية والكيماوية ذات التأثير على خواص اللن المعلل بالحرارة العالية وعلاقتها ظظاهرة زيادة اللزوجة كدلالة لتكوين البل باللبن قم تصنبع اللبن المجمع من مزارع نمونجية في لحدى مصانع الألبان الكبرى فى ثلاث دفعت وقم تحليل اللبن المعلمل بالتشخين

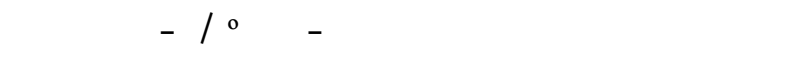

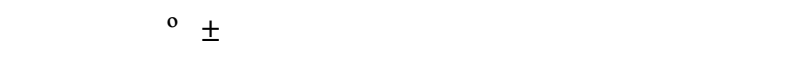
الخواص الطبيعية والكيماوية للبن طول فترة الحنظ التى

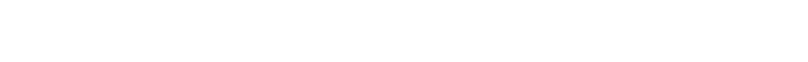

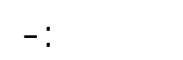

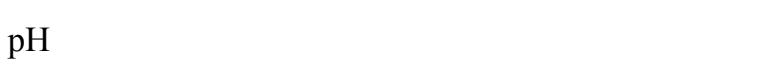
والتوصيل الكهرب مع ارفاع نسبة الحموضة واللزوجة والنيتروجن الغير بروتيف والغير كازيفي والكللسيوه 